\title{
Induction of Cyanide-insensitive Respiration in Moniliella tomentosa by the Use of $\boldsymbol{n}$-Propanol
}

\author{
By J. VANDERLEYDEN, L. HANSSENS AND H. VERACHTERT \\ Laboratory of Industrial Microbiology and Biochemistry, Catholic University of \\ Leuven, Kardinaal Mercierlaan 92, 3030 Heverlee, Belgium
}

(Received 26 July 1977; revised 30 September 1977)

\begin{abstract}
Cells of Moniliella tomentosa were grown in the presence of several short-chain alcohols $\left(\mathrm{C}_{1}\right.$ to $\left.\mathrm{C}_{4}\right), n$-Propanol and $n$-butanol induced the appearance of a mitochondrial cyanideinsensitive respiration without affecting the normal cytochrome chain whereas methanol and ethanol had no effect. Preliminary experiments indicated that the $C_{3}$ and $C_{4}$ alcohols interfered with oxidative phosphorylation, which explains the low growth yield and the accumulation of ethanol in the growth medium.
\end{abstract}

\section{INTRODUCTION}

Cyanide-resistant respiration occurs widely among plants and in the microbial world (for recent reviews, see Meeuwse, 1975; Henry \& Nyns, 1975; Lloyd, 1974). Previous studies showed that the yeast-like fungus Moniliella tomentosa may respire by means of two mitochondrial oxidase systems (Hanssens, 1975; Hanssens \& Verachtert, 1976). One system is mediated by $a$-, $b$ - and $c$-type cytochromes and is sensitive to cyanide and antimycin $\mathrm{A}$. The alternative system is insensitive to these inhibitors but can be specifically blocked by salicyl hydroxamic acid (SHAM), an inhibitor of the alternative oxidase in plants (Schonbaum et al., 1971). The normal and alternative oxidases form a branched electron transport system with the branchpoint at the level of coenzyme Q. The activity of the alternative oxidase in mitochondria can be markedly stimulated by AMP (Hanssens, 1975). A stimulative effect of AMP on the alternative oxidase was also found in mitochondria of Euglena gracilis grown under special conditions (Sharpless \& Butow, 1970) and Paramecium tetraurelia (Doussière, 1975). Under natural conditions $M$. tomentosa predominantly respires by means of the cytochrome system. When cells are grown in the presence of drugs which specifically interfere with mitochondrial function, the electron flux is almost completely mediated by the alternative oxidase (Hanssens, D'Hondt \& Verachtert, 1974). In this paper evidence is presented that cells grown in the presence of $0.6 \%(\mathrm{w} / \mathrm{v}) n$-propanol possess an almost equal activity of both pathways even though the activity of each one alone is capable of carrying the full respiratory flux.

\section{METHODS}

Organism. The organism used was the osmophilic obligate aerobic fungus Moniliella tomentosa, CBS 461.67. Growth medium and conditions. The liquid medium for cell cultivation (GYU medium) contained glucose $(10 \%, w / v)$, Oxoid yeast extract $(1 \%, w / v)$ and urea $(0 \cdot 1 \% \mathrm{w} / \mathrm{v})$. Other additions to this basic medium are detailed in the text. Cultures were grown in $100 \mathrm{ml}$ medium in $500 \mathrm{ml}$ Erlenmeyer flasks at $30^{\circ} \mathrm{C}$ on a reciprocal shaker. The aeration rate corresponded to a sulphite oxidation rate of $22 \mathrm{mmol}^{-1} \mathrm{~h}^{-1}$ as determined by the method of Cooper, Fernstrom \& Miller (1944).

Preparation of mitochondria. Mitochondria were obtained by mechanical disruption of the cells using a French press as described by Hanssens \& Verachtert (1976).

Respiration. Respiration was determined polarographically at $25^{\circ} \mathrm{C}$ with a Clark oxygen electrode inserted in a $3 \mathrm{ml}$ water-jacketed cuvette on a magnetic stirrer. Cell respiration was measured in 3,3-dimethyl- 
glutaric acid/ $\mathrm{NaOH}$ buffer $(20 \mathrm{~mm}, \mathrm{pH} 5 \cdot 8)$, containing $1 \%(\mathrm{w} / \mathrm{v})$ glucose. The reaction was started by the addition of cell suspension, corresponding to 3 to $4 \mathrm{mg}$ dry wt cells. The oxygen uptake of mitochondria was measured in sucrose buffer $(0.3 \mathrm{M}$-sucrose, $0.7 \mathrm{~mm}$-EDTA, $8 \mathrm{~mm}$-Tris/ $\mathrm{HCl} \mathrm{pH} 7.2)$ using 0.4 to $0.8 \mathrm{mg}$ mitochondrial protein. The substrates used were $0.5 \mathrm{~mm}$-NADH or $10 \mathrm{~mm}$-succinate. Respiration rates in whole cells are expressed as $\mu \mathrm{IO}_{2}$ consumed $\mathrm{h}^{-1}$ (mg dry wt cells) ${ }^{-1}$. Respiration rates in mitochondria are expressed as ng-atom $\mathrm{O}$ consumed $\mathrm{min}^{-1}$ ( $\mathrm{mg}$ protein) ${ }^{-1}$.

Reductase activities. Cytochrome $c$, ferricyanide and 2,6-dichlorophenolindophenol (DCIP) were used as electron acceptors in the determination of reductase activities in mitochondria. All measurements were made in sucrose buffer and recorded with a Unicam SP- 800 spectrophotometer at $25{ }^{\circ} \mathrm{C}$. The reactions were started by the addition of the substrate: $0.5 \mathrm{~mm}-\mathrm{NADH}, 10 \mathrm{~mm}$-succinate or $10 \mathrm{~mm}$-DL-lactate. The compositions of the standard assay mixtures (total volume $1 \cdot 1 \mathrm{ml}$ ) were as follows. (i) Substrate-cytochrome $c$ reductase: $1 \mathrm{ml}$ sucrose buffer; $1 \mathrm{~mm}-\mathrm{KCN} ; 0.06 \%$ (w/v) ferricytochrome $c$; and 0.04 to $0.06 \mathrm{mg}$ mitochondrial protein. (ii) Substrate-ferricyanide reductase: $1 \mathrm{ml}$ sucrose buffer; $1 \mathrm{~mm}-\mathrm{KCN}$; 1 mM-potassium ferricyanide; and 0.04 to $0.06 \mathrm{mg}$ mitochondrial protein. (iii) Substrate-DCIP reductase: $1 \mathrm{ml}$ sucrose buffer; $1 \mathrm{mM}-\mathrm{KCN}$; $0.1 \mathrm{~mm}$-DCIP; and 0.08 to $0.12 \mathrm{mg}$ mitochondrial protein. The millimolar absorption coefficients used in calculations of specific activities were 21.0 for cytochrome $c(550 \mathrm{~nm}), 1.03$ for potassium ferricyanide $(420 \mathrm{~nm})$ and $21 \cdot 0$ for DCIP $(600 \mathrm{~nm})$.

Analytical methods. (i) Ethanol, polyols and glucose. Cells were harvested by centrifugation and washed twice with water. The supernatants and the washings were combined and brought to volume before analytical determinations. Residual glucose was determined by the method of Somogyi-Nelson and total polyols by periodate oxidation, as described by Neish (1952). Ethanol was measured by gas chromatography.

(ii) Protein was assayed by the Lowry method (Lowry et al., 1951) with bovine serum albumin as reference standard. Mitochondrial proteins were solubilized with $0.2 \%(\mathrm{w} / \mathrm{v})$ deoxycholate before determination.

Materials. Biochemicals were obtained from Sigma. All chemicals used were of analytical grade.

\section{RESULTS}

Figure 1(a) shows the growth, respiration and fermentation pattern of $M$. tomentosa in GYU medium as a function of time. Oxygen uptake by the cells increased during the initial growth phase and remained high until the stationary phase was reached. The polyols formed were glycerol and erythritol, with a total concentration of about $25 \mathrm{mg}$ per $\mathrm{ml}$ growth medium. Ethanol production was very low. The final cell yield was about $1.5 \mathrm{~g}$ dry wt cells per $50 \mathrm{ml}$ medium, with a generation time of about $1.7 \mathrm{~h}$.

The sensitivity of the cells to cyanide and SHAM as a function of time throughout the life cycle is shown in Fig. 1(b). During exponential growth, the cyanide-resistant pathway did not account for more than a small fraction (about $5 \%$ ) of the total respiratory activity of the cells (measured in the absence of any inhibitor). At the end of the growth phase and during the subsequent stationary phase, only $50 \%$ inhibition of respiration occurred with $1 \mathrm{mM}-\mathrm{KCN}$. This low percentage inhibition in older cells can be attributed not only to the increased activity of the alternative pathway but also to the decreased activity of the cytochrome chain. The cyanide-resistant respiration never exceeded $12 \mu 1 \mathrm{O}_{2} \mathrm{~h}^{-1}$ (mg dry wt cells $)^{-1}$.

The results of similar experiments with cells grown in GYU medium supplemented with $0.6 \%(\mathrm{w} / \mathrm{v}) n$-propanol are given in Fig. $1(c, d)$. There was a sharp rise in oxygen uptake by the cells during the exponential growth phase (Fig. $1 c$ ). This high rate was maintained for about $35 \mathrm{~h}$, even during the early-stationary growth phase. Compared with the fermentation pattern of normal cells, there was a shift from polyol synthesis to ethanol accumulation in the medium [about $3 \%(\mathrm{w} / \mathrm{v})$ ]. The final cell yield was decreased from $1.5 \mathrm{~g}$ for normal cells to $0.6 \mathrm{~g}$ dry wt cells per $50 \mathrm{ml}$ medium in the presence of $n$-propanol, while the generation time increased two- to fourfold.

The effect of cyanide and SHAM on the respiration of cells grown in the presence of $n$-propanol is shown in Fig. 1(d). Cells in the late-exponential growth phase were insensitive to cyanide or SHAM. However, a residual respiration of $20 \%$ of the control value still existed when both inhibitors were used together. Similar experiments with methanol, ethanol and $n$-butanol (not shown) demonstrated that $n$-butanol could also induce cyanide- 

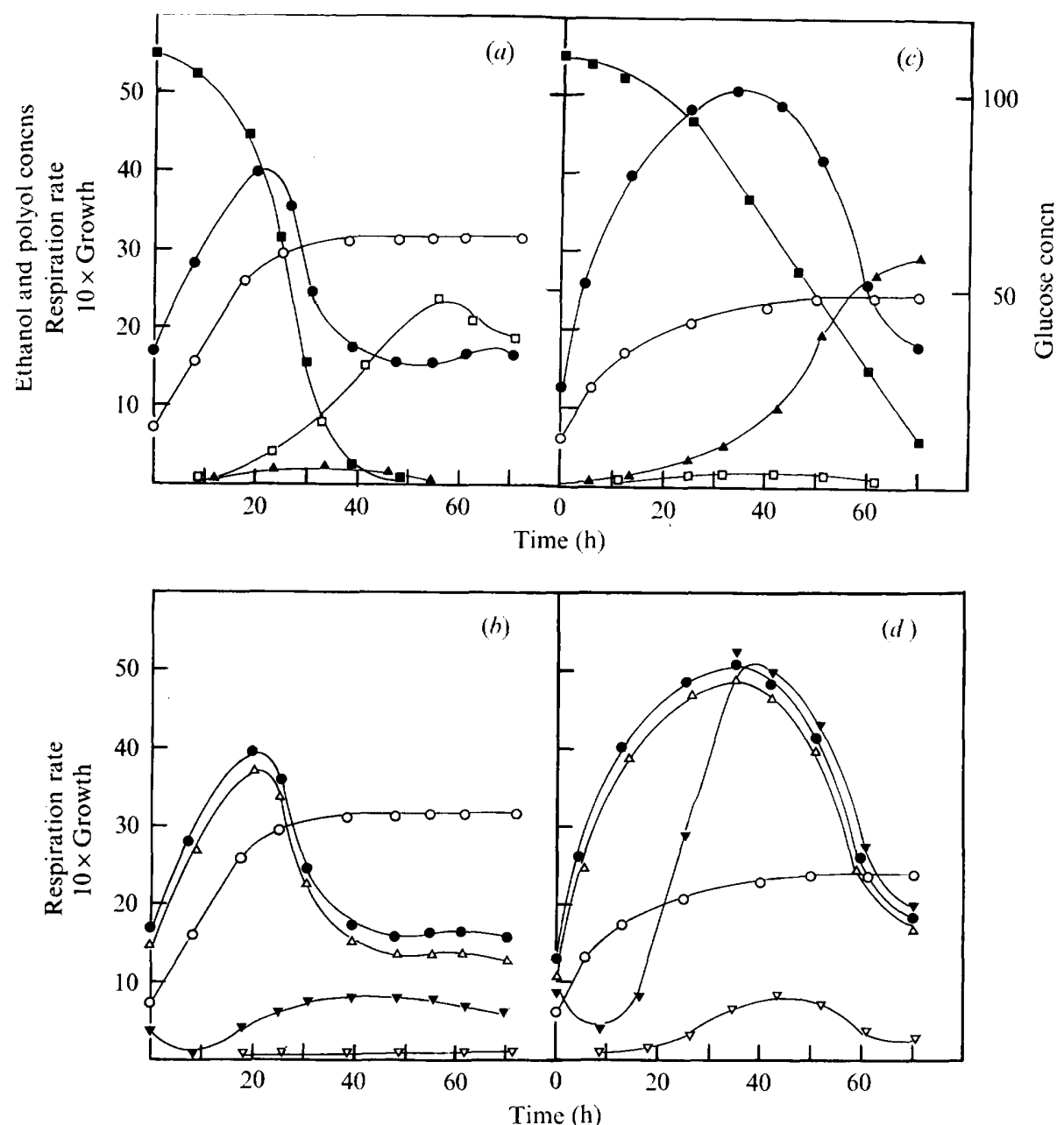

Fig. 1. Production of ethanol and polyols, respiration rate and inhibition of respiration by cyanide and salicyl hydroxamic acid (SHAM) during growth of Moniliella tomentosa in GYU medium $(a, b)$ and GYU medium containing $0.6 \%(\mathrm{w} / \mathrm{v}) n$-propanol $(c, d)$. Concentrations of ethanol, polyols and glucose are given as $\mathrm{mg}$ per $\mathrm{ml}$ growth medium. Growth is represented as $\log _{10} \mathrm{mg}$ dry wt cells per $50 \mathrm{ml}$ medium. The respiration rate $\left[\mu \mathrm{O} \mathrm{O}_{2} \mathrm{~h}^{-1}\right.$ (mg dry wt cells) $\left.{ }^{-1}\right]$ was measured polarographically. Final concentrations of inhibitors used in the respiratory measurements were $1 \mathrm{mM}-\mathrm{KCN}$ and $2.6 \mathrm{mM}-\mathrm{SHAM}$. Symbols in $(a)$ and $(c): \bigcirc$, growth; $O$, respiration; $\square$, glucose; $\square$, polyols; $\Delta$, ethanol. Symbols in $(b)$ and $(d): O$, growth; $O$, respiration in the absence of inhibitors; respiration in the presence of SHAM $(\triangle), K C N(\nabla)$ and $\operatorname{SHAM}+K C N(\nabla)$.

insensitive respiration, but methanol or ethanol had no effect. With $n$-propanol and $n$-butanol, the activity of the induced cyanide-insensitive respiration correlated with the concentration of the alcohol used. The optimum concentration of $n$-propanol was $0.6 \%(\mathrm{w} / \mathrm{v})$. The induction of the cyanide-insensitive respiration was not due to the selection of a mutant, since when cells grown in the presence of $n$-propanol were inoculated into the basic GYU medium, they became completely sensitive to cyanide after a few generations.

To see whether the resistance to cyanide or SHAM was due to a progressive lack of permeability of the cell wall or cell membrane, oxygen electrode assays were carried out with mitochondria. The degrees of sensitivity to cyanide and SHAM of mitochondria isolated from cells grown in the presence of $n$-propanol (' $n$-propanol' mitochondria) are illustrated by the results in Table 1 , which also includes results for mitochondria isolated from normal cells and for mitochondria from cells grown in the presence of ethidium 
Table 1. Oxidase activities in 'n-propanol' mitochondria, normal mitochondria and ' $E B$ ' mitochondria of Moniliella tomentosa

Oxidase activities were measured polarographically as described in Methods. Final concentrations were $0.5 \mathrm{~mm}$-NADH, $10 \mathrm{~mm}$-succinate, $1 \mathrm{~mm}-\mathrm{AMP}, 1 \mathrm{mM}-\mathrm{KCN}$ and $2.6 \mathrm{mM}-\mathrm{SHAM}$.

\begin{tabular}{|c|c|c|c|}
\hline \multirow[b]{2}{*}{ Additions } & \multicolumn{3}{|c|}{$\begin{array}{l}\text { Oxidase activity } \\
\text { [ng-atom } \mathrm{O} \text { consumed } \mathrm{min}^{-1} \\
\left.(\mathrm{mg} \text { protein })^{-1}\right]\end{array}$} \\
\hline & $\begin{array}{l}\text { 'n-Propanol' } \\
\text { mito- } \\
\text { chondria }\end{array}$ & $\begin{array}{l}\text { Normal } \\
\text { mito- } \\
\text { chondria }\end{array}$ & $\begin{array}{l}\text { 'EB' } \\
\text { mito- } \\
\text { chondria }\end{array}$ \\
\hline $\begin{array}{l}\text { NADH } \\
\text { NADH + SHAM } \\
\text { NADH + KCN } \\
\text { NADH + KCN + AMP } \\
\text { NADH + KCN + AMP + SHAM }\end{array}$ & $\begin{array}{r}299 \\
201 \\
18 \\
166 \\
5\end{array}$ & $\begin{array}{r}285 \\
282 \\
13 \\
13 \\
4\end{array}$ & $\begin{array}{r}24 \\
5 \\
20 \\
92 \\
0\end{array}$ \\
\hline $\begin{array}{l}\text { Succinate } \\
\text { Succinate + SHAM } \\
\text { Succinate + KCN } \\
\text { Succinate + KCN + AMP } \\
\text { Succinate + KCN + AMP + SHAM }\end{array}$ & $\begin{array}{r}220 \\
160 \\
16 \\
175 \\
4\end{array}$ & $\begin{array}{r}148 \\
151 \\
9 \\
9 \\
1\end{array}$ & $\begin{array}{r}22 \\
2 \\
18 \\
135 \\
9\end{array}$ \\
\hline
\end{tabular}

Table 2. Reductase activities in 'n-propanol' mitochondria, normal mitochondria and ' $E B$ ' mitochondria of Moniliella tomentosa

Reductase activities were measured spectrophotometrically as described in Methods. Final concentrations of substrates and AMP were $0.5 \mathrm{~mm}$-NADH, $10 \mathrm{~mm}$-succinate, $10 \mathrm{~mm}$-DL-lactate and 1 mM-AMP.

\begin{tabular}{|c|c|c|c|c|c|c|c|c|c|}
\hline \multirow[b]{3}{*}{ Additions } & \multicolumn{9}{|c|}{ Reductase activities [nmol $\mathrm{min}^{-1}$ (mg protein $)^{-1}$ ] } \\
\hline & \multicolumn{3}{|c|}{$\begin{array}{l}\text { ' } n \text {-Propanol" } \\
\text { mitochondria }\end{array}$} & \multicolumn{3}{|c|}{ Normal mitochondria } & \multicolumn{3}{|c|}{ 'EB' mitochondria } \\
\hline & $\mathrm{K}_{3} \mathrm{Fe}(\mathrm{CN})_{6}$ & DCIP & Cyt $c$ & $\mathrm{~K}_{3} \mathrm{Fe}(\mathrm{CN})_{\mathrm{e}}$ & ${ }_{6}$ DCIP & Cyt $c$ & $\mathrm{~K}_{3} \mathrm{Fe}(\mathrm{CN})_{6}$ & DCIP & Cyt $c$ \\
\hline $\begin{array}{l}\text { NADH } \\
\text { NADH + AMP }\end{array}$ & $\begin{array}{l}1874 \\
1874\end{array}$ & $\begin{array}{l}432 \\
432\end{array}$ & $\begin{array}{l}206 \\
206\end{array}$ & $\begin{array}{l}1404 \\
1404\end{array}$ & $\begin{array}{l}202 \\
202\end{array}$ & $\begin{array}{l}629 \\
629\end{array}$ & $\begin{array}{l}761 \\
761\end{array}$ & $\begin{array}{l}160 \\
160\end{array}$ & $\begin{array}{l}17 \\
17\end{array}$ \\
\hline $\begin{array}{l}\text { Succinate } \\
\text { Succinate + AMP }\end{array}$ & $\begin{array}{l}247 \\
453\end{array}$ & $\begin{array}{l}41 \\
83\end{array}$ & $\begin{array}{l}139 \\
163\end{array}$ & $\begin{array}{l}155 \\
155\end{array}$ & $\begin{array}{l}28 \\
28\end{array}$ & $\begin{array}{l}351 \\
351\end{array}$ & $\begin{array}{r}68 \\
146\end{array}$ & $\begin{array}{l}17 \\
17\end{array}$ & $\begin{array}{r}4 \\
24\end{array}$ \\
\hline $\begin{array}{l}\text { Lactate } \\
\text { Lactate + AMP }\end{array}$ & $\begin{array}{r}68 \\
309\end{array}$ & $\begin{array}{r}53 \\
104\end{array}$ & $\begin{array}{l}34 \\
64\end{array}$ & $\begin{array}{l}0 \\
0\end{array}$ & $\begin{array}{l}0 \\
0\end{array}$ & $\begin{array}{l}15 \\
15\end{array}$ & $\begin{array}{l}0 \\
0\end{array}$ & $\begin{array}{l}15 \\
15\end{array}$ & $\begin{array}{l}14 \\
14\end{array}$ \\
\hline
\end{tabular}

bromide ('EB' mitochondria). All mitochondria were isolated from cells in the earlystationary phase. The activity of the alternative pathway in mitochondria was determined in the presence of AMP. Succinate oxidation by ' $n$-propanol' mitochondria was almost completely insensitive to cyanide + AMP and to SHAM. The oxidation of added NADH was more strongly inhibited by cyanide + AMP than by SHAM. Almost complete inhibition occurred when both inhibitors were used together in the presence of AMP. The small residual fraction of the cell respiration in the presence of cyanide and SHAM is probably mediated by extra-mitochondrial pathways. The activity of the normal cytochrome chain in ' $n$-propanol' mitochondria is only slightly different from the activity of the cytochrome pathway in normal mitochondria, as can be seen from the corresponding oxidation rates in the presence of SHAM. Compared with 'EB' mitchondria, the activity of the alternative oxidase is higher in ' $n$-propanol' mitochondria, as can be seen from the oxidation rates in the presence of cyanide + AMP. The extent of the stimulation by AMP is higher in ' $n$ propanol' mitochondria than in 'EB' mitochondria, as can be seen from the oxidation rates in the presence of cyanide, with and without AMP. The effect of AMP on various partial 
mitochondrial activities is shown in Table 2. With NADH as substrate, the three reductase activities were not affected by AMP in ' $n$-propanol' mitochondria, normal mitochondria or 'EB' mitochondria. Succinate-ferricyanide reductase and succinate-cytochrome $c$ reductase in 'EB' mitochondria and ' $n$-propanol' mitochondria were stimulated by AMP. However, the percentage stimulation in ' $n$-propanol' mitochondria was less than in 'EB' mitochondria due to the presence of the normal cytochrome chain.

To elucidate the mechanism(s) of induction of the alternative oxidase in $M$. tomentosa by $n$-propanol, preliminary experiments were carried out to investigate the effect of $n$-propanol on mitochondria isolated from cells grown in the presence of $n$-propanol. $n$-Propanol was not oxidized by these mitochondria, and the oxidation of NADH or succinate was not affected in the presence of $n$-propanol. On the contrary, $n$-propanol ( $5 \mathrm{mM}$ ) was an inhibitor of oxidative phosphorylation, as determined by loss of respiratory control through the inhibition of the ADP-induced state-3 rate of oxygen uptake.

\section{DISCUSSION}

We have demonstrated that the mitochondrial cyanide-resistant respiration in $M$. tomentosa can be induced by the use of $n$-propanol, while the respiratory capacity of the normal cytochrome chain is not affected. The alternative pathway in ' $n$-propanol' mitochondria has properties in common with the one found in ' $E B$ ' mitochondria, except for the oxidation of DL-lactate and the oxidation of succinate with DCIP as electron acceptor (see Table 2). The different effects of AMP on mitochondria isolated from cells grown in the presence of $n$-propanol or EB with DL-lactate as substrate suggest a different entrance for the electrons in the branched respiratory chain. Hanssens \& Verachtert (1976) postulated that in mitochondria isolated from cells grown in the presence of EB, DL-lactate provides electrons at the level of cytochrome $c$. The stimulation by AMP in mitochondria isolated from cells grown in the presence of $n$-propanol points to a lactate dehydrogenase providing electrons before the site of action of AMP. However, this does not explain the results for the oxidation of DL-lactate with DCIP as electron acceptor. As the same difference was found in the succinate-DCIP reductase activity, a more complex site of action of AMP must be postulated.

The mechanism by which $n$-propanol induces the alternative pathway is not clear. Although the normal respiratory chain is present, and mitochondria from cells grown in the presence of $n$-propanol can perform normal oxidative phosphorylation, the use of $n$-propanol leads to a reduction in growth yield, an increased generation time and a shift from polyol synthesis to ethanol production. This might confirm that $n$-propanol in vivo may uncouple respiration and oxidative phosphorylation.

Thus, whenever the operation of the normal respiratory chain is impaired in $M$. tomentosa (using ethidium bromide, chloramphenicol, antimycin A or $n$-propanol), the alternative pathway is induced. In plant tissues possessing a potentially active alternative respiratory pathway, this pathway can also be induced with ethylene or propylene (Solomos \& Laties, 1975, 1976; Chin \& Frenkel, 1977), and it would be interesting to find out whether these compounds can inhibit the normal phosphorylating respiratory pathway. If the inhibition of oxidative phosphorylation leads to the induction of an alternative electron transport pathway, the mechanisms by which this occurs remain to be found.

\section{REFERENCES}

Chin, C-K. \& Frenkel, C. (1977). Upsurge in respiration and peroxide formation in potato tubers as influenced by ethylene, propylene and cyanide. Plant Physiology 59, 515-518.

Cooper, C. M., Fernstrom, G. A. \& Miller, S. A. (1944). Performance of agitated gas-liquid contactors. Industrial and Engineering Chemistry 36, 504-509.
DoussIÈRE, J. (1975). La respiration cyano-résistante chez Paramecium tetraurelia. Thèse de Docteur d'Université, Université Scientifique et Médicale de Grenoble, France.

Hanssens, L. (1975). An alternative electron transport pathway in the osmophilic fungus Moniliella tomentosa. Ph.D. thesis, Catholic University of Leuven, Belgium. Agricultura 23, 1-102. 
Hanssens, L. \& Verachtert, H. (1976). Adenosine 5'-monophosphate stimulated cyanide-insensitive respiration in mitochondria of Moniliella tomentosa. Journal of Bacteriology 125, 829-835.

HaNSSENS, L., D'HONDT, E. \& Verachtert, H. (1974). Cyanide-insensitive respiration in Moniliella tomentosa and the effect of drugs on respiration and polyol biosynthesis. Archives of Microbiology 98, 339-349.

Henry, M-F. \& Nyns, E. J. (1975). Cyanide-insensitive respiration. An alternative mitochondrial pathway. Sub-Cellular Biochemistry 4, 1-65.

LLOYD, D. (1974). Pathways of electron transport alternative to the phosphorylating respiratory chain. In The Mitochondria of Microorganisms, pp. 137-158. Edited by D. Lloyd. London, New York and San Francisco: Academic Press.

Lowry, O. H., Rosebrough, N. J., FARR, A. L. \& RANDALL, R. J. (1951). Protein measurement with the Folin phenol reagent. Journal of Biological Chemistry 193, 265-275.

MeeuwSE, B. J. D. (1975). Thermogenic respiration in aroids. Annual Review of Plant Physiology 26, 117-126.

NeISH, A. C. (1952). Analytical methods for bacterial fermentations. National Research Council of Canada 2952, 34-37.

Schonbaum, G. R., Bonner, W. D. Jr, Storey, B. T. \& BAHR, J. T. (1971). Specific inhibition of the cyanide-insensitive respiratory pathway in plant mitochondria by hydroxamic acids. Plant Physiology 47, 124-128.

Sharpless, T. K. \& Butow, R. A. (1970). An inducible alternate oxidase in Euglena gracilis mitochondria. Journal of Biological Chemistry 245, 58-70.

Solomos, T. \& Laties, G. G. (1975). The mechanism of ethylene and cyanide action in triggering the rise in respiration in potato tubers. Plant Physiology 55, 73-78.

Solomos, T. \& Laties, G. G. (1976). Induction by ethylene of cyanide-resistant respiration. Biochemical and Biophysical Research Communications 70, 663-671. 